\title{
Wybrane instrumenty wsparcia mieszkaniowego w Republice Czeskiej. Studium przypadku Brna i Ostrawy
}

Artur Włodzimierz Parys*

\section{Streszczenie}

Artykuł dotyczy implementacji koncepcji mieszkalnictwa społecznego w Republice Czeskiej (uwarunkowania powstania koncepcji i jej rozwoju, przyjęte zasady oraz skutki wdrożenia w życie).

Koncepcja mieszkalnictwa społecznego Republiki Czeskiej na lata 20152025 jest dokumentem ramowym określającym kierunek tworzenia systemu mieszkalnictwa społecznego dla osób potrzebujących mieszkań w Republice Czeskiej. Celem koncepcji mieszkalnictwa społecznego w Republice Czeskiej jest stworzenie nowego systemu, który powinien opierać się na obecnym systemie interwencji państwa, regionów i gmin w zakresie mieszkalnictwa, usług społecznych oraz świadczeń socjalnych. Wsparcie w zakresie mieszkalnictwa występuje nie tylko w formie materialnego dostarczania zasobu mieszkaniowego, lecz również w formie zasiłków wypłacanych przez Urząd Pracy Republiki Czeskiej. Państwo czeskie wspiera grupy społeczne o niskich dochodach w pokrywaniu ich kosztów mieszkaniowych. Do podstawowych subsydiów mieszkaniowych w Republice Czeskiej należą zasiłek mieszkaniowy (příspěvek na bydleni) oraz dodatek mieszkaniowy (doplatek na bydleni).

Celem opracowania jest ocena skuteczności wybranych programów wsparcia mieszkalnictwa w miastach Brnie oraz Ostrawie. W artykule pojęcie ,skuteczność”

\footnotetext{
* Artur Włodzimierz Parys, magister, Uniwersytet Łódzki, Wydział Ekonomiczno-Socjologiczny, artur.parys@edu.uni.lodz.pl.

(C) by the author, licensee Łódź University - Łódź University Press, Łódź, Poland. This article is an open access article distributed under the terms and conditions of the Creative Commons Attribution license CC BY-NC-ND 4.0 (https://creativecommons.org/licenses/by-nc-nd/4.0/)
} 
dotyczy realizowanych lokalnych polityk mieszkaniowych badanych miast, natomiast pojęcie „efektywność” odnosi się do instrumentów wsparcia mieszkaniowego Brna i Ostrawy. Lokalne programy pomocy mieszkaniowej oraz subsydiów mieszkaniowych badanych miast są często określane w sposób bardzo ogólny, co w połączeniu z brakiem danych statystycznych o wysokości tych świadczeń i ich liczbie utrudnia przeprowadzenie skutecznej analizy porównawczej. Z tego powodu wybór programów poddanych empirycznej i ilościowej porównawczej analizie efektywności został ograniczony do następujących subsydiów: zasiłek mieszkaniowy (príspěvek na bydleni) oraz dodatek mieszkaniowy (doplatek na bydleni). Problem badawczy sformułowano następująco: czy analizowane subsydia mieszkaniowe - zasiłek mieszkaniowy (přispěvek na bydleni) oraz dodatek mieszkaniowy (doplatek na bydleni) - zmniejszają obciążenie finansowe kosztami mieszkaniowymi osób, których dochody nie wystarczają na pokrycie tych kosztów?

Badane miasta poddano porównawczej analizie ze względu na różne instrumenty wsparcia mieszkaniowego. W pracy empirycznej oraz ilościowej ocenie skuteczności zostały poddane wybrane instrumenty polityki mieszkaniowej, które zostały oparte na liczbie i wysokości wypłat poszczególnych analizowanych subsydiów mieszkaniowych. Zastosowaną metodą badawczą jest krytyczna analiza danych literaturowych, a także wyników porównawczych analiz ilościowych i analiz komparatywnych.

Dokonana ocena skuteczności wybranych programów wsparcia mieszkalnictwa w miastach Brno i Ostrawa wykazała następujące zależności: w przeciwieństwie do innych ocenianych instrumentów pomocy mieszkaniowej zasiłek mieszkaniowy (př́spěvek na bydleni) oraz dodatek mieszkaniowy (doplatek na bydleni) są świadczeniami uzależnionymi od dochodów, a odsetek gospodarstw domowych uprawnionych do tych świadczeń jest wyraźnie najwyższy wśród gospodarstw domowych o najniższych dochodach. Przeprowadzona analiza porównawcza wykazała, że oba subsydia mieszkaniowe, tj. zasiłek mieszkaniowy (přispěvek na bydleni) oraz dodatek mieszkaniowy (doplatek na bydleni), przyczyniają się do zmniejszenia poziomu nierówności dochodowych w czeskim społeczeństwie.

Slowa kluczowe: potrzeby mieszkaniowe, lokalne programy mieszkaniowe, subsydia mieszkaniowe

JEL: R21, R28 


\section{Wstęp}

Interwencje regulacyjne państwa w sektorze mieszkaniowym mają w Republice Czeskiej stosunkowo długą tradycję. Już po I wojnie światowej, w okresie pierwszej republiki (1918-1939), polityka mieszkaniowa oprócz wspierania budowy nowych kwater obejmowała działania na rzecz ochrony lokatorów i regulacji czynszów ze względu na powojenny niedobór mieszkań i gwałtowne zwiększenie się kosztów budowy. Wspierano również budowę małych mieszkań dla słabszych ekonomicznie grup ludności. W bezpośrednim okresie powojennym regulacja czynszów dotyczyła praktycznie wszystkich mieszkań czynszowych (nájemní byty). W związku z ich ciągłą budową niektóre rodzaje mieszkań oraz silniejsze dochodowo grupy najemców zostały wyłączone z reglamentacji. Czynsze zmniejszały się stopniowo, ogłaszając maksymalne procentowe stawki zwiększenia się czynszów w stosunku do przedwojennego poziomu bazowego. Celem tych działań było, podobnie jak w innych krajach europejskich, całkowite zniesienie regulacji czynszów (Sunega 2005, s. 271-272).

Polityka mieszkaniowa państwa czeskiego po 1948 r. opierała się na zasadzie, że mieszkanie jest tak ważnym dobrem w życiu człowieka, że zwiększające się koszty jego budowy, utrzymania oraz zarządzania nie powinny być przekładane wyłącznie na wydatki gospodarstw domowych. W krajach bloku komunistycznego polityka mieszkaniowa związana była z nacjonalizacją własności prywatnej i ideologicznym podejściem do kwestii egalitaryzmu. Jej negatywnymi konsekwencjami były stale zwiększające się kwoty dotacji państwowych na finansowanie zarówno budowy mieszkań, jak również ich eksploatacji, zarządzania i utrzymania, a także niewystarczające inwestycje w istniejące zasoby mieszkaniowe oraz nierówny dostęp do mieszkań. Finansowanie mieszkalnictwa odbywało się w formie dotacji celowych państwa na inwestycje mieszkaniowe, wkładów państwowych na spółdzielcze mieszkalnictwo oraz wkładów państwowych na indywidualne mieszkalnictwo (Lérová 1983). Komunalne mieszkalnictwo obejmowało wyłącznie budowę budynków mieszkalnych z mieszkaniami czynszowymi, które pozostawały w administracji komitetów narodowych (lub zarządzanych i finansowanych przez nie przedsiębiorstw mieszkaniowych) i były w całości finansowane z dotacji państwowych. W przypadku mieszkań gminnych - komunalnych (komunalnych bytu) czynsze zostały zamrożone ustawowo na poziomie z 1964 r. do 1991 r. Stosowano administracyjną reglamentację mieszkań, lecz mimo oficjalnie głoszonej tezy o odpowiedzialności społeczeństwa za zapewnienie mieszkania każdemu obywatelowi prowadziło to do niesprawiedliwości, przekupstwa i faworyzowania (Sunega 2005, s. 271-272).

Podobnie jak w innych dziedzinach gospodarki również w sektorze mieszkaniowym po 1989 r. rozpoczęto transformację od reglamentacyjnego systemu gospodarki mieszkaniowej do systemu opartego na respektowaniu zasad rynkowych. 
Rola państwa, zgodnie z pierwszymi koncepcjami polityki mieszkaniowej opartymi na zasadach neoliberalnych, miała być ograniczona do stworzenia warunków dla powstania rynku mieszkaniowego.

W ramach decentralizacji władzy państwowej i przywrócenia samorządności lokalnej nastąpiło nieodpłatne przekazanie zasobów mieszkaniowych z własności państwowej na własność komunalną. Transfer rozpoczął się w $1991 \mathrm{r}$. i według niektórych źródeł (Sýkora 2003) dotyczył 877 tys. mieszkań $(23,5 \%$ zasobów mieszkaniowych), a według innych (Slavata 2000, s. 8-9) 1,44 mln mieszkań (około 39\% zasobów mieszkaniowych w Republice Czeskiej). Autor Sýkora (Sýkora 2003) podaje, że własnością państwa pozostawały tylko te domy, w których ponad jedna trzecia powierzchni użytkowej była wykorzystywana do celów niemieszkalnych (Slavata 2000, s. 8-9). Ponieważ gminy zostały postawione w roli administratorów zasobów mieszkaniowych, przeniesiono na nie odpowiedzialność za kształtowanie lokalnej polityki mieszkaniowej i zmuszono do ponoszenia kosztów eksploatacji, zarządzania i utrzymania nowo nabytych nieruchomości. Przekazaniu zasobów mieszkaniowych nie towarzyszyło jednak wzmocnienie budżetów gmin o dodatkowe środki finansowe; gminy nie były przygotowane do nowej roli pod względem metodologicznym, nie opracowano zasad ani zaleceń dotyczących zarządzania zasobami mieszkaniowymi. Na początku lat 90. w większości gmin środki zebrane z tytułu czynszu nie wystarczały na pokrycie kosztów związanych z bieżącą eksploatacją i utrzymaniem zasobów mieszkaniowych, co stanowiło dodatkowe obciążenie dla budżetów gmin. Konsekwencją tego był utrzymujący się stan długotrwałego niedoinwestowania zasobów mieszkaniowych oraz wynikająca z niego próba prywatyzacji przez gminy przynajmniej części zasobów mieszkaniowych i odciążenia własnych budżetów. W związku z przekazaniem dużej części państwowych zasobów mieszkaniowych na własność gminy zakładano, że gminy w pewnej mierze je sprywatyzują. Nie sformułowano jednak ważnych w skali kraju zaleceń co do tego, jaka część zasobów mieszkaniowych powinna zostać sprywatyzowana przez gminy, a jaka powinna pozostać $w$ ich posiadaniu. Nie sformułowano także zaleceń co do cen, w jakich powinny być sprzedawane komunalne zasoby mieszkaniowe, nie określono zasad wyboru domów/mieszkań do prywatyzacji, nie sformułowano zaleceń co do warunków płatności, rozliczeń z nowymi właścicielami ani dysponowania środkami uzyskanymi ze sprzedaży części zasobów mieszkaniowych. Wszystkie te kwestie pozostawiono w gestii gmin, co z konieczności doprowadziło do dużego zróżnicowania warunków, w jakich odbywała się prywatyzacja. Początek procesu prywatyzacji można datować już na 1991 r. Mimo braku dokładnych danych statystycznych na temat jego przebiegu można stwierdzić (zwłaszcza na podstawie danych z badania Instytutu Rozwoju Terytorialnego w Brnie), że jego największy rozmach przypadł na drugą połowę lat 90. (Sunega 2005, s. 271-272). 
W przeciwieństwie do innych krajów Europy Środkowej i Wschodniej, najemcy w Republice Czeskiej (jak również w Polsce) nie uzyskali ,prawa do zakupu" (right to buy), które pozwoliłoby im wystąpić o przejęcie mieszkania na własność, tak aby gmina musiała spełnić ten wniosek. W rezultacie sektor komunalnych mieszkań czynszowych w Republice Czeskiej (podobnie jak w Polsce) jest nadal stosunkowo dobrze reprezentowany w porównaniu z innymi krajami Europy Środkowo-Wschodniej (Sunega 2005, s. 271-272).

\section{Ocena efektywności różnych instrumentów wsparcia mieszkaniowego w Republice Czeskiej na przykładzie miast Brna i Ostrawy}

\section{Brno}

Brno jest drugim co do wielkości miastem w Republice Czeskiej pod względem liczby mieszkańców i powierzchni. W Brnie i jego najbliższej okolicy koncentrują się średnie i większe przedsiębiorstwa oraz rozwijają się usługi edukacji i kształcenia na wszystkich poziomach (szkolnictwo podstawowe, średnie i wyższe). Obecna powierzchnia miasta wynosi $230,2 \mathrm{~km}^{2}$ (Tematický akční plan pro oblast sociálního bydlení ve městě Brně 2019-2022, s. 4). Statutowe miasto Brno jest podzielone na 29 dzielnic miejskich. Pod koniec 2018 r. Brno liczyło 380681 mieszkańców, z czego 196633 stanowiły kobiety. Liczba przebywających w mieście zwiększa się codziennie o 100-160 tys. osób, które przyjeżdżają do Brna w celach zarobkowych lub edukacyjnych. Obszar metropolitalny Brna zamieszkuje około 600 tys. mieszkańców. Następuje proces urban sprawl-zmiana miejsca zamieszkania osób w wieku produkcyjnym, które przenoszą się na podmiejskie tereny, co zmniejsza liczbę osób mieszkających w mieście i zwiększa ich średni wiek (Tematický akční plan pro oblast sociálního bydlení ve městě Brně 2019-2022, s.4).

Zaangażowanie w tworzenie Koncepcji Mieszkalnictwa Społecznego w Brnie sięga 2016 r., kiedy to Statutowe Miasto Brno zostało wybrane jako jedno z szesnastu miast i gmin do testowania Koncepcji Mieszkalnictwa Społecznego Republiki Czeskiej 2015-2025 (zatwierdzonej przez czeski rząd 12 października 2015 r.). Na podstawie umowy o współpracy pomiędzy Statutowym Miastem Brno a Ministerstwem Pracy i Spraw Społecznych Republiki Czeskiej (zwanym dalej Ministerstwem Pracy i Spraw Społecznych) w kwietniu 2017 r. rozpoczęto realizację trzyletniego projektu pilotażowego testowania koncepcji mieszkalnictwa społecznego w Brnie (Koncepce sociálního bydlení v Brně Analytická a návrhová část 2020-2030, s. 8). 
Celem mieszkalnictwa społecznego jest zaspokojenie potrzeb mieszkaniowych osób, które z powodu niekorzystnej sytuacji finansowej nie są w stanie znaleźć mieszkania na warunkach rynkowych ${ }^{1}$. Potrzeby mieszkaniowe są jednak znacznie szerszym pojęciem i mają wpływ na ogólną jakość życia. Osoby o niezaspokojonych potrzebach mieszkaniowych są narażone na większe ryzyko dla zdrowia. Ubóstwo mieszkaniowe odbija się na psychice, finansach, zatrudnieniu, nie zapewnia wystarczającego spokoju i przestrzeni do nauki etc., a więc naraża ludzi na ciągły kryzys egzystencjalny, który uniemożliwia realizację innych aspektów życia.

W związku z tym konkretyzacja głównych celów polityki mieszkaniowej powinna nawiązywać do potrzeb mieszkaniowych obywateli i popytu mieszkaniowego zgłaszanego w danym czasie i miejscu. Ponieważ sposób realizacji „prawa do (za) mieszkania" będzie miał wpływ na model społeczny funkcjonujący w danym kraju (Lis 2005), wobec tego (...) kształt potrzeb mieszkaniowych i ich zmiana w czasie będzie decydującym determinantem wyznaczania celów głównych polityki mieszkaniowej (Lis 2017, s. 114). Dlatego też przewidywanie zmian w sferze potrzeb mieszkaniowych nie tylko będzie decydować o skuteczności prowadzonej polityki mieszkaniowej (widzianej jako wiązka instrumentów), lecz również może wpływać na efektywność poszczególnych instrumentów tejże polityki (Lis 2017, s. 114).

Ponieważ ustawa o mieszkalnictwie społecznym nie została jeszcze przyjęta w Czechach, obecnie to gminy są głównie odpowiedzialne za ten obszar. W dłuższej perspektywie korzystne społecznie jest kompleksowe i odpowiedzialne rozwiązywanie problemu mieszkaniowego, zgodnie z zaleceniami MPSV (Ministerstwo Pracy i Spraw Socjalnych Republiki Czeskiej): „Zapewnienie mieszkań na jasno określonych warunkach jest jednym z podstawowych narzędzi rozwiązywania problemów społecznych i gospodarczych na poziomie lokalnym i regionalnym. Jeśli gmina ma do dyspozycji to narzędzie, może skutecznie chronić się przed ubóstwem i powstawaniem miejscowości wykluczonych społecznie oraz rozwiązywać poważne sytuacje kryzysowe swoich mieszkańców" (Sociální bydlení - metodická a informační podpora v oblasti sociálních agend). Konieczne jest ustalenie standardów i kryteriów dla mieszkalnictwa społecznego w taki sposób, aby sprzyjało ono również integracji społecznej.

Na podstawie potrzeby rozwoju mieszkalnictwa społecznego i zgodnie z koncepcją rządową powstaje koncepcja mieszkalnictwa społecznego na poziomie lokalnym, która opiera się na doświadczeniach Rady Miasta Brna wynikających

\footnotetext{
${ }^{1}$ W swojej koncepcji mieszkalnictwa socjalnego Komisja Europejska (2020/C 429/13), działając jako europejski organ ochrony konkurencji, jest bardzo restrykcyjna: stwierdza, że mieszkalnictwo socjalne powinno być zarezerwowane wyłącznie dla „osób znajdujących się w niekorzystnej sytuacji lub mniej uprzywilejowanych grup społecznych, które ze względu na wypłacalność nie są w stanie znaleźć mieszkania na warunkach rynkowych", https://eur-lex.europa.eu/legal-content/PL/ TXT/PDF/?uri=CELEX:52020IE1076\&from=EN.
} 
z pilotażowego projektu Rapid Re-Housing. Projekt ten był skierowany do rodzin z dziećmi i dzięki decyzji Rady Miasta Brna po raz pierwszy w Czechach została przeniesiona oraz wdrożona innowacyjna metoda społeczna - Housing First. Podejście to opiera się na prostym założeniu, że potrzeby mieszkaniowe powinny być rozwiązywane przede wszystkim poprzez to, czego ludziom najbardziej brakuje, czyli mieszkania. Oznacza to, że potrzeby mieszkaniowej nie można zastąpić żadną usługą zakwaterowania w ramach usług społecznych lub pobytem w komercyjnym schronisku. Dopiero po ustabilizowaniu sytuacji mieszkaniowej można skutecznie rozwiązać inne problemy społeczne lub zdrowotne, z którymi boryka się gospodarstwo domowe.

Grupę docelową mieszkalnictwa społecznego stanowią osoby potrzebujące mieszkań, które mają również niskie dochody. Kategoria mieszkań społecznych nie obejmuje zatem mieszkań chronionych lub mieszkań specjalnego przeznaczenia, jak również innych kategorii mieszkań komunalnych, które są oddzielnie zdefiniowane w regulaminie wynajmu mieszkań w lokalach należących do Statutowego Miasta Brna (Koncepce sociálního bydlení v Brně Analytická a návrhová část 2020-2030, s. 8).

\section{Rozmieszczenie terytorialne mieszkań społecznych i ich udział w dzielnicach miejskich}

W 2020 r. mieszkania społeczne prowadzone przez miasto znajdowały się tylko $\mathrm{w}$ ośmiu dzielnicach, ponadto $\mathrm{w}$ trzech przypadkach były to mieszkania $\mathrm{w}$ niepowierzonych budynkach mieszkalnych. Tak zwane mieszkania niepowierzone (tzn. mieszkania $\mathrm{w}$ domach, które nie zostały powierzone $\mathrm{w}$ zarząd danego obwodu miejskiego i są zarządzane bezpośrednio przez miasto) oraz tak zwane mieszkania powierzone, które są w tym celu zapewniane przez obwód miejski, są przydzielane jako mieszkania społeczne (z kompleksowym wsparciem lub bez). Liczba mieszkań niepowierzonych jest niewielka (597 mieszkań w 64 budynkach mieszkalnych), zaś w zakresie mieszkań powierzonych miasto boryka się z faktem, że większość dzielnic, którym powierzono środki na zarządzanie mieszkaniami, nie przekazuje ich na cele mieszkalnictwa społecznego.

Spośród 23 obwodów miejskich, które zarządzają mieszkaniami komunalnymi, tylko pięć udostępniło co najmniej jedno mieszkanie na cele społeczne. Trzy obwody miejskie (Lišeňn, Vinohrady, Židenice) zapewniły od 1 do 3 mieszkań, dwa obwody miejskie (Brno-střed i Brnosever) zapewniły więcej niż 10 mieszkań. Mieszkań społecznych nie zapewnia (lub praktycznie nie zapewnia) 13 obwodów miejskich, w których znajduje się stosunkowo duża liczba mieszkań komunalnych.

$\mathrm{Z}$ analizy przedstawionych powyżej danych liczbowych wynika, że czeskie obwody miejskie $\mathrm{w}$ większości niechętnie angażują się w mieszkalnictwo 
społeczne w swoich zasobach mieszkaniowych. Wśród najczęściej wymienianych powodów jest obawa przed stratami finansowymi spowodowanymi obniżeniem czynszu w mieszkaniach społecznych. Kolejną obawą jest możliwość powstania długów czynszowych czy dodatkowych kosztów związanych z koniecznymi remontami. W celu poprawy sytuacji związanej z mieszkalnictwem społecznym w Brnie program prac Urzędu Miasta Brno został również rozszerzony o przeprowadzanie, dokumentowanie oraz weryfikację dochodów (dwa razy w roku), odnawianie umów najmu (raz w roku oraz w indywidualnych przypadkach) i rozpatrywanie skarg.

Z ogólnej liczby 227 mieszkań społecznych w 2019 r. gminy przekazały 133 mieszkania z zasobu mieszkaniowego, który został im powierzony. Jest to niespełna $60 \%$ mieszkań społecznych w mieście, natomiast pozostałe 94 mieszkania społeczne (40\%) miasto zapewniło z mieszkań niepowierzonych dzielnicom miasta (Koncepce sociálního bydlení v Brně Analytická a návrhová část 2020-2030, s. 8).

\section{Analiza ilościowa - spis gospodarstw domowych potrzebujących mieszkań w mieście Brno}

Gospodarstwa domowe, które nie mają wystarczających dochodów na utrzymanie lub odpowiednie mieszkanie bądź są obciążone wypadkami losowymi, kwalifikują się do otrzymania zasiłku z tytułu trudnej sytuacji materialnej (dávky pomoci $v$ hmotné nouzi). Z dostępnych danych Urzędu Pracy Republiki Czeskiej (Úřadu práce $\check{C} R$ ) wynika, że liczba wypłaconych świadczeń z tytułu pomocy w trudnej sytuacji materialnej w 2017 r. na terenie gminy Brno wyniosła łącznie 91 375, opiewając na kwotę 366975000 CZK (Tematický akční plan pro oblast sociálního bydlení ve městě Brně 2019-2022 s. 9-10.).

Analiza danych przedstawionych na wykresie 1 i 2 wskazuje na zmniejszenie się liczby wypłaconych świadczeń społecznych z 70336 w 2014 r. do 55285 w 2017 r. Zmniejszenie się liczby świadczeń wypłaconych oraz wydatków na świadczenia nastąpiło po $2015 \mathrm{r}$. i trend ten utrzymywał się do $2017 \mathrm{r}$. Kwota płatności z tytułu dodatków mieszkaniowych nie uległa jednak znacznym zmianom w latach objętych przeglądem. 
Wykres 1. Liczba świadczeń wypłaconych w sytuacji poważnego zagrożenia wykluczeniem mieszkaniowym wypłaconych przez gminę Brno w latach 2014-2017

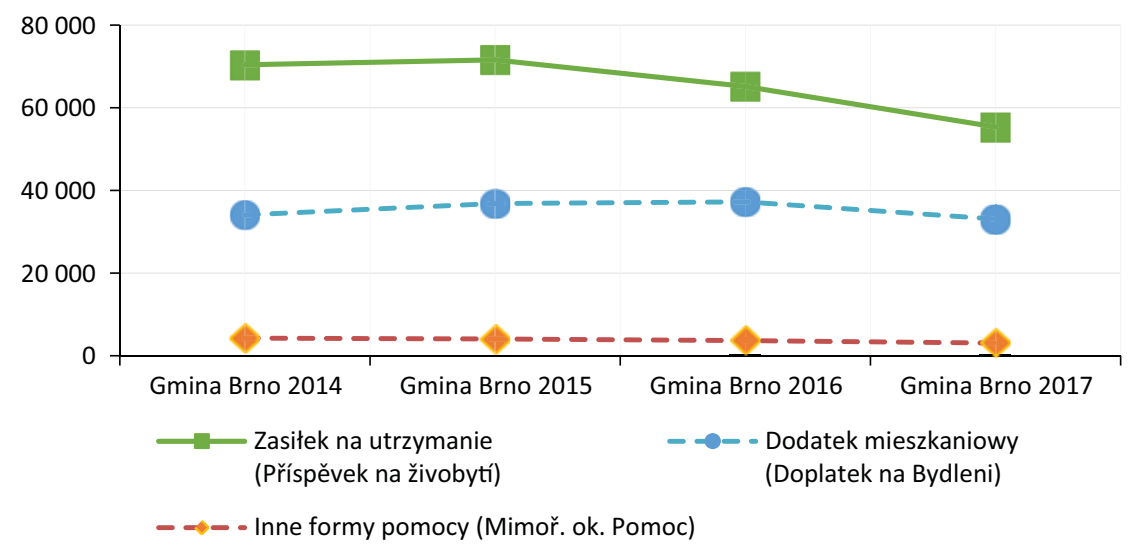

Źródło: opracowanie własne na podstawie Úřadu práce ČR.

Wykres 2. Wydatki na świadczenia dotyczące istotnych potrzeb (w tysiącach CZK; z wyłączeniem skutków dodatkowych płatności, nadpłat i zwrotów) w latach 2014-2017

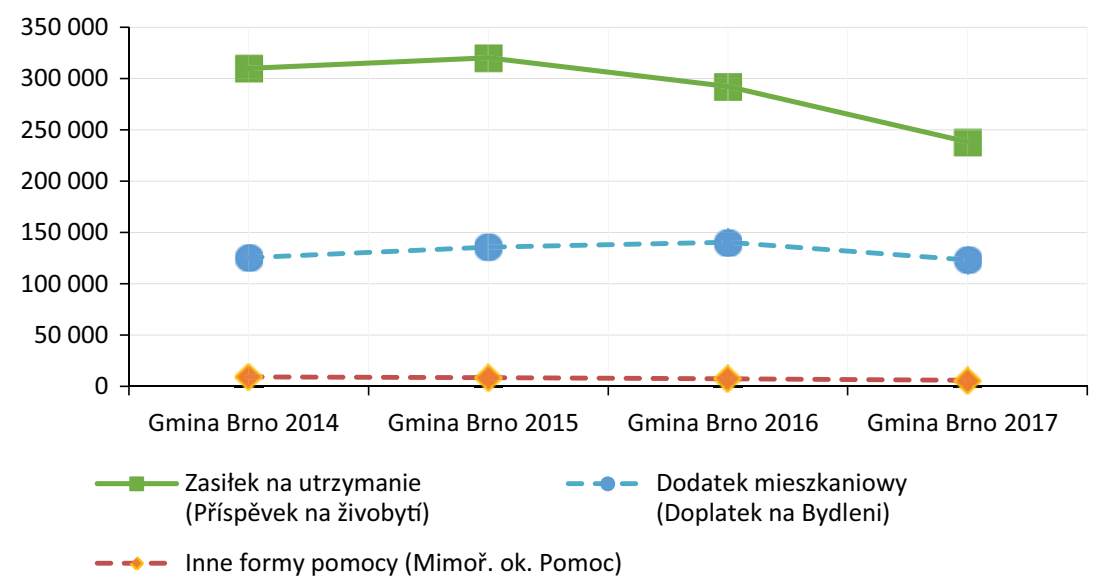

Źródło: opracowanie własne na podstawie Úřadu práce ČR.

Wyobrażenie o liczbie gospodarstw domowych otrzymujących zasiłek na utrzymanie można również uzyskać na podstawie analizy liczby zasiłków wypłaconych w danym miesiącu. Wynika to z faktu, że określone gospodarstwa domowe są liczone więcej niż jeden raz w ogólnej liczbie świadczeń wypłacanych w ciągu roku (w zależności od tego, przez ile miesięcy otrzymują świadczenie). W czerwcu 2018 r. było to 2352 gospodarstw domowych, w których mieszkało łącznie 5312 osób. W ogólnej liczbie gospodarstw domowych otrzymujących świadczenie było 1020 gospodarstw z co najmniej jednym dzieckiem. W gospodarstwach tych mieszkało łącznie 2013 dzieci. 
Przytoczony powyżej Raport Wykluczenia Mieszkaniowego z 2018 r. wykazał, że znaczna liczba gospodarstw domowych znajdujących się w potrzebie mieszkaniowej z różnych powodów nie otrzymuje dodatku mieszkaniowego (doplatek na bydleni). Średnio tylko $60 \%$ bezdzietnych gospodarstw domowych w ośrodkach pomocy mieszkaniowej, $60 \%$ gospodarstw domowych z dziećmi w schroniskach i $40 \%$ bezdzietnych gospodarstw domowych przebywających przez dłuższy czas w schroniskach otrzymuje dodatek mieszkaniowy, nie licząc pracowników (Tematický akční plan pro oblast sociálního bydlení ve městě Brně 2019-2022, s. 9-10).

\section{Mieszkalnictwo społeczne w Brnie na tle innych miast}

Podsumowując, mieszkania społeczne prowadzone przez miasto i te prowadzone przez organizacje non-profit, to w sumie 306 mieszkań społecznych różnego typu w Brnie. Interesujące byłoby porównanie wielkości zasobów mieszkań społecznych w Brnie z innymi miastami Czech i Moraw. Niestety, dla większości miast niezbędne dane nie są publicznie dostępne. Jednym z niewielu miast, o których możemy dowiedzieć się czegoś więcej, jest miasto statutowe Ostrawa² (290 000 mieszkańców). Na koniec 2018 r. w Ostrawie znajdowało się łącznie 726 mieszkań społecznych (tj. dwukrotnie więcej niż liczba mieszkań społecznych w Brnie), a przydział kolejnych 100 mieszkań społecznych planowany był na lata 2020-2021. Podczas gdy w Brnie na 1000 mieszkańców przypada 0,93 mieszkania społecznego, w Ostrawie jest to 2,52 mieszkania społecznego; z czego 102 z tych mieszkań są zarządzane przez Statutowe Miasto Ostrawa, 137 przez prywatnego właściciela, a pozostałe mieszkania społeczne (487) są zarządzane przez 13 organizacji non-profit (Statutární město Ostrava 2019, Akční plán koncepce sociálního bydlení statutárního města Ostravy). W kolejnym projekcie dotyczącym mieszkań społecznych Ostrawa przewiduje również współpracę z prywatnym właścicielem, który udostępni 10 lokali na cele mieszkań społecznych. Jest to ten sam prywatny właściciel, który już wynajmuje mieszkania na cele społeczne i który posiada ponad 40 tys. mieszkań w regionie morawsko-śląskim (Koncepce sociálního bydlení v Brně Analytická a návrhová část 2020-2030, s. 20).

\footnotetext{
${ }^{2}$ Spośród nich 221 mieszkań zostało oddanych do użytku przez 6 ostrawskich dzielnic, 3 przez miasto, 490 przez prywatnych właścicieli i 12 przez organizacje non-profit. W 102 mieszkaniach wsparcia udzielili pracownicy gminy, w pozostałych 624 mieszkaniach wsparcia udzielili pracownicy społeczni z jednej z 14 uczestniczących w projekcie organizacji pozarządowych.
} 


\section{Ostrawa}

Ostrawa jest stolicą kraju morawsko-śląskiego, które leży w północno-wschodniej części Republiki Czeskiej³. Pod względem powierzchni i liczby mieszkańców Ostrawa jest trzecim co do wielkości miastem w Republice Czeskiej. Dzisiejsza Ostrawa zajmuje powierzchnię $214,24 \mathrm{~km}^{2}$. Miasto jest obecnie podzielone na 23 obwody miejskie, z których najbardziej zaludnione to Ostrawa-Południe, Poruba, Morawska Ostrawa i Przywóz.

Wiele osób żyje w warunkach niespełniających minimalnych norm mieszkaniowych lub w ogóle nie posiada mieszkania. Miasto Ostrawa, które już od dłuższego czasu ma do czynienia $\mathrm{z}$ takimi sytuacjami w sferze polityki mieszkaniowej, nie miało zatwierdzonego dokumentu strategicznego $\mathrm{w}$ tej sprawie. Wobec tego, na podstawie zidentyfikowanych potrzeb, w 2017 r. została przygotowana Koncepcja Mieszkalnictwa Społecznego Statutowego Miasta Ostrawy (Koncepce sociálního bydlení statutárního města Ostravy). Celem ogólnym koncepcji było stworzenie kompleksowego systemu mieszkalnictwa społecznego zaspokajającego potrzeby mieszkańców miasta, którzy zostali zakwalifikowani jako osoby potrzebujące mieszkań.

Projekt Koncepcja Mieszkalnictwa Społecznego Statutowego Miasta Ostrawy przedstawia ogólny cel i cztery główne obszary, które dotyczą zapobiegania utracie mieszkań, określenia pojemności zasobów mieszkaniowych miasta, systemu mieszkalnictwa społecznego oraz finansowania mieszkalnictwa społecznego. Wszystkie działania są zgodne z zasadami narodowej koncepcji mieszkalnictwa społecznego Republiki Czeskiej 2015-2025 (Koncepce sociálního bydlení statutárního města Ostravy, s. 4).

Stan i wielkość zasobów mieszkaniowych są podstawowym punktem wyjścia do kształtowania polityki mieszkaniowej, która determinuje decyzje o dalszych działaniach i rozwiązaniach problemów mieszkaniowych. W Ostrawie w latach 2009-2016 nastąpiło ogólne zmniejszenie liczby lokali mieszkalnych będących własnością gminnych jednostek organizacyjnych o 244. 31 grudnia 2016 r. pod zarządem obwodów miejskich Ostrawy znajdowały się łącznie 12872 lokale mieszkalne, tj. 1037 budynków mieszkalnych. Część mieszkań będących własnością miasta i powierzonych obwodom znajduje się w budynkach, w których są inni właściciele mieszkań, oraz w budynkach zarządzanych przez stowarzyszenia właścicieli nieruchomości. Na zmniejszenie zasobów mieszkaniowych w poszczególnych obwodach miasta w ciągu ostatnich 12 lat wpłynęła ich szeroka prywatyzacja (Koncepce sociálního bydlení statutárního města Ostravy 2017, s. 33).

${ }^{3}$ Aktualny podział administracyjny Czech obejmuje 13 krajów samorządowych oraz miasto wydzielone Praga (Samosprávné kraje), które są jednostkami samorządu terytorialnego z własną administracją (odpowiednik polskiego województwa). 


\section{Świadczenia społeczne (Sociální dávky) / Świadczenia z państwowej pomocy społecznej (Dávky státní sociální podpory)}

\section{Analiza porównawcza świadczeń mieszkaniowych Brna i Ostrawy}

Od 1 stycznia 2012 r. podejmowaniem decyzji i administrowaniem świadczeniami społecznymi nieobjętymi ubezpieczeniem zajmuje się jeden organ, którym jest Urząd Pracy Republiki Czeskiej (Úrady práce $\check{C} R$ ). Świadczenia te reguluje ustawa Dz.U. nr 117/1995 o państwowym wsparciu społecznym w obowiązującym brzmieniu (zákon č. 117/1995 Sb., o státní sociální podpoře, ve znění pozdějších předpisů).

Zasilek mieszkaniowy (Přispěvek na bydleni) jest najważniejszym państwowym świadczeniem społecznym, które dotyczy mieszkania w Republice Czeskiej. Warunki uzyskania prawa do zasiłku mieszkaniowego są określone w § 24 ustawy o państwowej pomocy społecznej. Państwo partycypuje w kosztach mieszkaniowych rodzin i osób o niskich dochodach. Właściciel lub najemca lokalu mieszkalnego zameldowany na pobyt stały w tym lokalu ma prawo do dodatku mieszkaniowego, jeżeli 30\% dochodu rodziny nie wystarcza na pokrycie kosztów mieszkaniowych, a jednocześnie 30\% dochodu rodziny jest niższe od odpowiednich kosztów normatywnych określonych przepisami prawa. Struktura tego zasiłku została przedstawiona w tabeli 1 (Koncepce sociálního bydlení statutárního města Ostravy 2017, s. 33).

Tabela 1. Struktura zasiłku mieszkaniowego (Př́spěvek na bydleni) w powiecie ostrawskim w latach 2012-2018

\begin{tabular}{|c|c|c|c|c|}
\hline Rok & $\begin{array}{c}\text { Liczba } \\
\text { wyplaconego } \\
\text { zasilku } \\
\text { mieszkaniowego / } \\
\text { rok }\end{array}$ & $\begin{array}{c}\text { Średnia liczba } \\
\text { wyplaconych } \\
\text { zasilków/miesiąc }\end{array}$ & $\begin{array}{c}\text { Kwota } \\
\text { wyplaconego } \\
\text { zasilku } \\
\text { mieszkaniowego / } \\
\text { rok w Kč }\end{array}$ & $\begin{array}{c}\text { Średnia kwota } \\
\text { wypłaconych } \\
\text { zasilków/miesiąc } \\
\text { w Kč }\end{array}$ \\
\hline 2012 & 137971 & 11498 & 419714987 & 34976249 \\
\hline 2013 & 165734 & 13811 & 538138688 & 44844891 \\
\hline 2014 & 193953 & 16163 & 664166426 & 55347202 \\
\hline 2015 & 197216 & 16435 & 712938143 & 59411512 \\
\hline 2016 & 196268 & 16356 & 733942201 & 61161850 \\
\hline 2017 & 198204 & 16517 & 717067071 & 59755589 \\
\hline 2018 & 175603 & 14634 & 671619869 & 55968322 \\
\hline
\end{tabular}

Źródło: opracowanie własne na podstawie Úřad práce ČR - krajská pobočka v Ostravě, kontaktní pracoviště Ostrava (2012-2018). 
$\mathrm{Z}$ analizy danych zawartych $\mathrm{w}$ tabeli 1 oraz przedstawionych na wykresach 3 i 4 możemy zaobserwować zwiększenie się liczby osób korzystających z zasiłku mieszkaniowego (Př́spěvek na bydleni) w latach 2012-2016 o prawie 4900 gospodarstw domowych oraz zwiększenie się wypłat w tym samym okresie o ponad $314 \mathrm{mln}$ CZK (czyli 26,2 $\mathrm{mln}$ CZK/miesiąc), co jest wskaźnikiem zwiększającej się liczby gospodarstw domowych i ich trudnej sytuacji w zakresie utrzymania mieszkania. To znaczy, że koszty mieszkaniowe stanowią taki wydatek dla budżetu domowego, że do jego pokrycia potrzebne jest wsparcie finansowe ze strony państwa. Rok 2016 stanowił szczytowy okres w wysokości wypłacanych zasiłków mieszkaniowych. W 2017 r. liczba beneficjentów zwiększyła się o 161 gospodarstw domowych, jednakże wypłacona kwota zmniejszyła się o 16,9 mln (czyli o 1,4 mln CZK rocznie).

Wykres 3. Liczba wypłaconego zasiłku mieszkaniowego (Příspěvek na bydleni) na rok w powiecie ostrawskim w latach 2012-2018

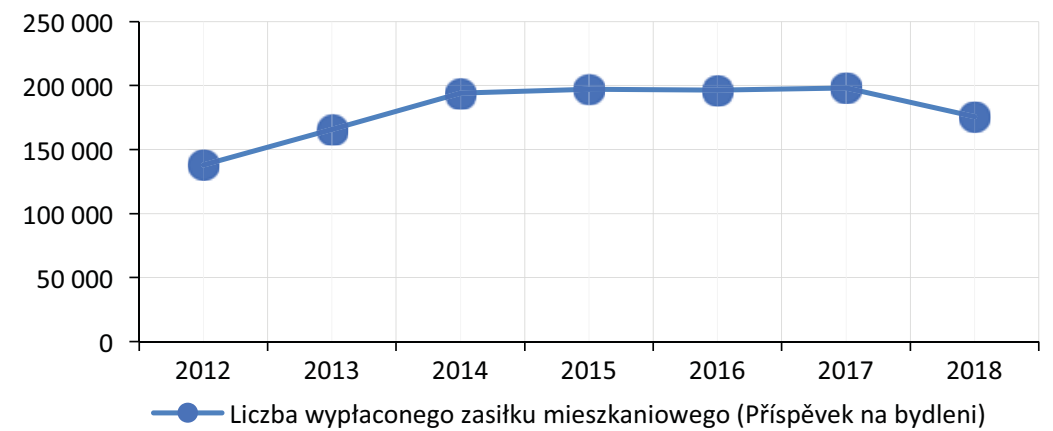

Źródło: opracowanie własne na podstawie Úřad práce ČR - krajská pobočka v Ostravě, kontaktní pracoviště Ostrava (2012-2018).

Wykres 4. Kwota wypłaconego zasiłku mieszkaniowego (Př́spěvek na bydleni)/rok w Kč w powiecie ostrawskim w latach 2012-2018

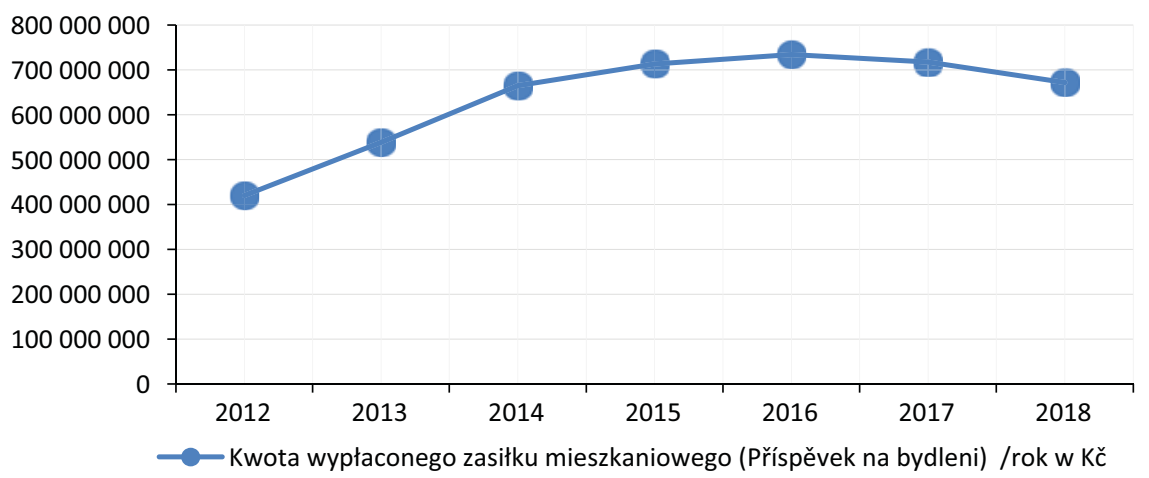

Źródło: opracowanie własne na podstawie Úřad práce ČR - krajská pobočka v Ostravě, kontaktní pracoviště Ostrava (2012-2018). 
W 2018 r. nastąpiło zmniejszenie się liczby beneficjentów oraz wielkości wypłat, przy czym średnia liczba gospodarstw domowych zmniejszyła się o 1883 w porównaniu z 2017 r., a wypłaty wyniosły $45,4 \mathrm{mln}$ CZK. Roczna liczba gospodarstw domowych zmniejszyła się odpowiednio o 45,8 mln CZK i 3,8 mln CZK miesięcznie.

Dla porównania na wykresach 5 i 6 została przedstawiona liczba i wartość kwoty wypłaconego zasiłku mieszkaniowego (př̀spěvek na bydleni) w Brnie i Ostrawie w latach 2012-2018. Dane zostały pozyskane z czeskiego urzędu statystycznego (Český statistický úruad) i dotyczą świadczeń z państwowej pomocy społecznej (Vyplacené dávky státni sociálni podpory). W Brnie w latach 2012-2016 nastąpiło znaczne zwiększenie się liczby wypłaconego zasiłku mieszkaniowego (o 44214 ) oraz kwoty wypłacanych środków (o 254900 tys. CZK). W Ostrawie w latach 2012-2016 również nastąpiło znaczne zwiększenie się liczby wypłaconego zasiłku mieszkaniowego (o 64 017) oraz kwoty wypłacanych środków (o 305653 tys. CZK). Natomiast w 2017 i 2018 r. zarówno liczba, jak i kwota wypłaconego zasiłku mieszkaniowego zmniejszyły się. Wobec tego powyższa analiza porównawcza potwierdza wnioski z analizy wykresów 3 i 4. Możemy zatem powiedzieć, że tempo zmian liczby i kwoty wypłat zasiłku mieszkaniowego w Brnie i Ostrawie jest podobne.

Wykres 5. Liczba wypłaconych świadczeń z państwowej pomocy społecznej (Vyplacené dávky státní sociálni podpory - Přispěvek na bydleni) w Brnie i Ostrawie w latach 2012-2018

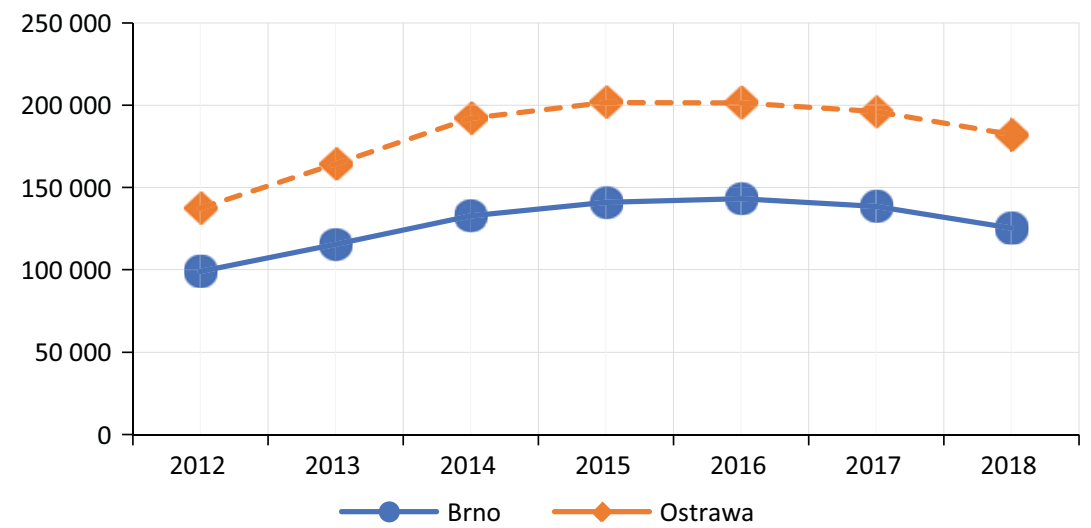

Źródło: opracowanie własne na podstawie Český statistický úřad. 
Wykres 6. Kwota wypłaconych świadczeń w tys. CZK (hodnota vyplacených dávek v tis. Kč). Zasiłek mieszkaniowy w latach 2012-2018

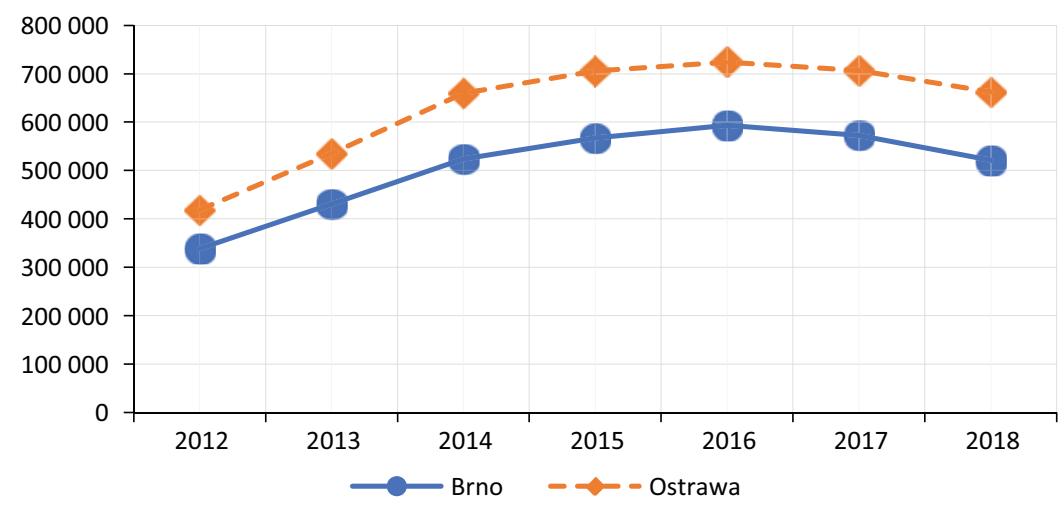

Źródło: opracowanie własne na podstawie Český statistický úřad.

Dodatek mieszkaniowy (doplatek na bydleni) jest obok zasiłku mieszkaniowego (Př́spěvek na bydleni - państwowa pomoc społeczna) kolejną możliwością pomocy osobom, które pomimo zasiłku mieszkaniowego nie są w stanie z własnych środków pokryć kosztów związanych z użytkowaniem mieszkania. Dodatek mieszkaniowy może również wspomóc finansowo osoby, które nie mają prawa do zasiłku mieszkaniowego (np. korzystają z niestandardowej formy zamieszkania - tj. mieszkają w mieszkaniach na zasadzie podnajmu, mieszkają w noclegowniach, mieszkają w lokalach niemieszkalnych lub nie spełniają warunku stałego zameldowania w mieszkaniu, na które mają umowę najmu), ale mimo to ich łączny dochód jest na tyle niski, że po opłaceniu kosztów mieszkaniowych nie mają już pieniędzy na utrzymanie (Koncepce sociálního bydlení statutárního města Ostravy 2017, s. 33).

Tabela 2. Liczba i struktura dodatku mieszkaniowego (doplatek na bydleni) w powiecie ostrawskim w latach 2012-2018

\begin{tabular}{|c|c|c|c|c|}
\hline Rok & $\begin{array}{c}\text { Liczba } \\
\text { wyplaconych } \\
\text { dodatków/rok }\end{array}$ & $\begin{array}{c}\text { Średnia liczba } \\
\text { wyplaconych } \\
\text { dodatków/miesiąc }\end{array}$ & $\begin{array}{c}\text { Kwota } \\
\text { wyplaconych } \\
\text { dodatków/rok } \\
\text { w Ǩc }\end{array}$ & $\begin{array}{c}\text { Średnia kwota } \\
\text { wyplaconych } \\
\text { dodatków/miesiąc } \\
\text { w Kč }\end{array}$ \\
\hline 2012 & 53106 & 4426 & 174611205 & 14550934 \\
\hline 2013 & 79285 & 6607 & 293226259 & 24435522 \\
\hline 2014 & 93735 & 7811 & 356850639 & 29737553 \\
\hline 2015 & 96483 & 8040 & 368311365 & 30692614 \\
\hline 2016 & 88635 & 7386 & 350840445 & 29236704 \\
\hline 2017 & 79691 & 6641 & 299666989 & 24972249 \\
\hline 2018 & 59578 & 4965 & 236302009 & 19691834 \\
\hline
\end{tabular}

Źródło: opracowanie własne na podstawie Úřad práce ČR - krajská pobočka v Ostravě, kontaktní pracoviště Ostrava (2012-2018). 
Podobnie jak w przypadku zasiłku mieszkaniowego (přispěvku na bydleni), w latach 2012-2016 nastąpiło znaczne zwiększenie się liczby beneficjentów (o prawie 3 tys.) oraz kwoty wypłacanych środków (odpowiednio o 176,2 $\mathrm{mln}$ CZK i 14,7 mln $\mathrm{CZK} /$ miesiąc). Aktualne dane wskazują jednak na zmniejszenie się liczby beneficjentów i kwoty wypłat w zestawieniu pomiędzy 2015 a $2016 \mathrm{r}$. W przypadku dodatku mieszkaniowego (doplatek na bydleni) szczyt liczby beneficjentów i kwoty wypłaconych środków nastąpił w 2015 r., a od tego roku utrzymuje się tendencja spadkowa.

W 2017 r. średnia liczba beneficjentów zmniejszyła się o 745 gospodarstw domowych, a wolumen środków zmniejszył się o 51,2 mln euro w stosunku do 2018 r. odpowiednio 4,3 mln CZK rocznie, czyli 1,5 mln CZK miesięcznie. Rok 2018 oznaczał dalsze zmniejszenie średniej liczby gospodarstw domowych o 1676 (!) oraz zmniejszenie kwoty płatności uzupełniających o 63,4 mln CZK miesięcznie, czyli 5,3 mln CZK rocznie.

\section{Podsumowanie}

W artykule analizie porównawczej poddano lokalne programy polityki mieszkaniowej koncentrujące się na poprawie dostępu do mieszkań społecznych oraz wybrane instrumenty wsparcia mieszkaniowego w miastach Brno i Ostrawa w szczególności zasiłek mieszkaniowy (Př́spěvek na bydleni) oraz dodatek mieszkaniowy (doplatek na bydleni). Z przeprowadzonych analiz wynika, że:

- Pod koniec 2018 r. w mieście Ostrawa znajdowało się łącznie 726 mieszkań społecznych (tj. dwukrotnie więcej niż liczba mieszkań społecznych w Brnie);

- W 2018 r. w mieście Brno na 1000 mieszkańców przypadało 0,93 mieszkania społecznego, a w mieście Ostrawa przypadało 2,52 mieszkania społecznego;

- Na zmniejszenie zasobów mieszkaniowych w poszczególnych obwodach miasta Brna w ciągu ostatnich 12 lat wpłynęła ich szeroka prywatyzacja;

- W przeciwieństwie do innych ocenianych instrumentów pomocy mieszkaniowej, zasiłek mieszkaniowy (príspěvek na bydleni) oraz dodatek mieszkaniowy (doplatek na bydleni) są świadczeniami uzależnionymi od dochodów;

- Odsetek gospodarstw domowych uprawnionych do tych świadczeń jest wyraźnie najwyższy wśród gospodarstw domowych o najniższych dochodach, podczas gdy gospodarstwa domowe uprawnione do świadczeń prawie nie występują wśród gospodarstw domowych o najwyższych dochodach;

- Rozkład tych form wsparcia jest również wyraźnie przechylony na korzyść gospodarstw domowych o najniższych dochodach;

- Tempo zmian liczby i kwoty wypłat zasiłku mieszkaniowego (přispěvek na bydleni) w Brnie i Ostrawie jest takie samo; 
- Z przeprowadzonej analizy porównawczej liczby i kwot zasiłku mieszkaniowego (přispěvek na bydleni) oraz dodatku mieszkaniowego (doplatek na bydleni) w badanych miastach wykazano, że oba subsydia mieszkaniowe zmniejszają obciążenie finansowe kosztami mieszkaniowymi osób, których dochody nie wystarczają na pokrycie tych kosztów.

\section{Bibliografia}

Agentura pro sociální začleňování, Tematický akční plan pro oblast sociálního bydlení ve městě Brně 2019-2022, https://www.socialni-zaclenovani.cz/ wpcontent/uploads/BRNO_TAP_soc_bydleni_ZOR7.pdf (data dostępu: 24.07.2021).

Český statistický úr̆ad, https://www.czso.cz (data dostępu: 24.07.2021).

EUR-Lex - Baza aktów prawnych Unii Europejskiej, Opinia Europejskiego Komitetu Ekonomiczno-Spolecznego. Powszechny dostęp do godziwego, zrównoważonego $i$ przystęnego cenowo mieszkalnictwa $w$ perspektywie dtugoterminowej, https://eur-lex.europa.eu/legal-content/PL/TXT/PDF/?uri=CELEX:52020IE1076\&from=EN (data dostępu: 24.07.2021).

Koncepce sociálního bydlení statutárního města Ostravy 2017, s. 33.

Koncepce sociálního bydlení v Brně Analytická a návrhová část 2020-2030, s. $22-23$.

Lérová I. (1983), Úloha bydlení v sociálně ekonomickém rozvoji, Praha.

Lis, P. (2005), Koncepcje polityki mieszkaniowej, „Zeszyt naukowy”, nr 31, Katedra Polityki Gospodarczej i Planowania Rozwoju, Akademia Ekonomiczna w Poznaniu, Poznań.

Lis P. (2017), Myślenie prewidystyczne w polityce mieszkaniowej, t. 29, $\mathrm{nr} 4$, s. 113-126.

Projekt Podpora sociálního bydlení, Sociální bydlení - metodická a informační podpora $v$ oblasti sociálnich agend, http://socialnibydleni.mpsv.cz./cs/ (data dostępu: 24.07.2021).

Slavata D. (2000), Vybrané problémy obecni bytové politiky. Veřejná správa $2 / 2000,8-9,25$.

Sunega P. (2005), The Effectiveness of Selected Housing Policy Subsidies in the Czech Republic, ,Sociologický časopis/Czech Sociological Review”, t. 41, s. 271-272. https://doi.org/10.13060/00380288.2005.41.2.05

Sýkora L. (2003), Between the State and the Market: Local Government and Housing in the Czech Republic, s. 48-116, [w:] M. Lux (red.), Housing Policy: An End or a New Beginning?, Budapest.

Úřad práce $\breve{C}$, https://www.uradprace.cz/moravskoslezsky-kraj (data dostępu: 24.07.2021). 


\section{Summary}

\section{Selected instruments of housing support in the Czech Republic A case study of Brno and Ostrava}

The Concept of Social Housing of the Czech Republic for 2015-2025 is a framework document setting the direction for the creation of a social housing system for people in need of housing in the Czech Republic. The aim of the concept of social housing in the Czech Republic is to create a new system that should be built on the current system of state, regional and municipal interventions in housing, social services and social benefits. Housing support is also provided in the form of benefits paid by the Employment Office of the Czech Republic. The Czech state supports low-income social groups in covering their housing costs. The basic housing subsidies in the Czech Republic are: housing allowance (př́spěvek na bydleni) and housing supplement (doplatek na bydleni).

The purpose of this study is to evaluate the effectiveness of selected housing support programs in Brno and Ostrava. In the article, the term effectiveness refers to the implemented local housing policies of the examined cities, while the term efficiency refers to the housing support instruments of Brno and Ostrava. The objectives of the local housing assistance and housing subsidy programs of the examined cities are often defined in very general terms, which, combined with the lack of statistical data on the amount of these benefits and their number, makes it difficult to conduct an effective comparative analysis. For this reason, the selection of programs subjected to empirical and quantitative comparative effectiveness analysis was limited to the following: housing allowance (prisspěvek na bydleni) and housing supplement (doplatek na bydleni). The research problem was formulated as follows: Do the analyzed housing subsidies: housing benefit (přispěvek na bydleni) and housing allowance (doplatek na bydleni) contribute to reducing the level of income inequality in Czech society?

The studied cities were subjected to a comparative analysis due to different housing support instruments. In the paper, selected housing policy instruments were empirically and quantitatively evaluated for their effectiveness, which was based on the number and amount of payments of individual housing benefits analyzed. The research methods used are critical literature analysis, comparative quantitative analysis, comparative analysis. The used sources of foundational data in the study are: Úradu práce ČR and Český statistický úrad.

The completed assessment of the effectiveness of selected housing support programs in Brno and Ostrava showed the following correlations: at the end of 2018 there were a total of 726 social housing units in Ostrava (i.e. twice the number of social housing units in Brno), in contrast to the other assessed housing support instruments, housing benefit (př́spěvek na bydleni) and housing 
allowance (doplatek na bydleni) are income-based benefits. The percentage of households entitled to these benefits is clearly the highest among households with the lowest income. The comparative analysis carried out showed that both housing subsidies: housing benefit (príspěvek na bydleni) and housing allowance (doplatek na bydleni) contribute to reducing the level of income inequality in the Czech society.

Keywords: housing needs, local housing programs, housing subsidies 